\title{
Identification of a New Enamovirus Associated with Citrus Vein Enation Disease by Deep Sequencing of Small RNAs
}

\author{
Mari Carmen Vives, Karelia Velázquez, José Antonio Pina, Pedro Moreno, José Guerri, and Luis Navarro
}

Centro de Protección Vegetal y Biotecnología, Instituto Valenciano de Investigaciones Agrarias (IVIA), Ctra. Moncada-Náquera Km. 4.5, Moncada, 46113 Valencia, Spain.

Accepted for publication 23 May 2013.

\begin{abstract}
Vives, M. C., Velázquez, K., Pina, J. A., Moreno, P., Guerri, J., and Navarro, L. 2013. Identification of a new enamovirus associated with citrus vein enation disease by deep sequencing of small RNAs. Phytopathology 103:1077-1086.

To identify the causal agent of citrus vein enation disease, we examined by deep sequencing (Solexa-Illumina) the small RNA (sRNA) fraction from infected and healthy Etrog citron plants. Our results showed that virus-derived sRNAs (vsRNAs): (i) represent about $14.21 \%$ of the total sRNA population, (ii) are predominantly of 21 and 24 nucleotides with a biased distribution of their $5^{\prime}$ nucleotide and with a clear preva-

Enamovirus. The genomic RNA (gRNA) sequence of a new virus, provisionally named Citrus vein enation virus (CVEV), was completed and characterized. The CVEV gRNA was found to be single-stranded, positive-sense, with a size of 5,983 nucleotides and five open reading frames. Phylogenetic comparisons based on amino acid signatures of the RNA polymerase and the coat protein clearly classifies CVEV within the genus Enamovirus. Dot-blot hybridization and reverse transcription-polymerase chain reaction tests were developed to detect CVEV in plants affected by vein enation disease. CVEV detection by these methods has already been adopted for use in the Spanish citrus quarantine, sanitation, and certification programs.
\end{abstract} lence of those of $(+)$ polarity, and (iii) derive from all the viral genome, although a prominent hotspot is present at a $5^{\prime}$-proximal region. Contigs assembled from vsRNAs showed similarity with luteovirus sequences, particularly with Pea enation mosaic virus, the type member of the genus
Additional keywords: cDNA probes, Luteoviridae, molecular hybridization, virus detection.
Citrus vein enation was first described in California by Wallace and Drake (63) as a graft-transmissible disease inciting enations on secondary veins of sour orange (Citrus aurantium L.) and other reactive species, and then in South Africa by McClean (40) who demonstrated that the disease is transmitted by Toxoptera citricida (Kirk.); thus, a viral aetiology was assumed for this disease. Fraser (16) reported a disease causing woody galls on rough lemon ( $C$. jambhiri Lush) rootstock in Australia, but later it was shown that both vein enation and woody gall diseases were induced by the same pathogen $(65,66)$. Vein enation/woody gall disease has been observed in many citrus growing areas from the five continents, including Argentina, Australia, Brazil, China, Japan, India, Peru, South Africa, Spain, United States, or Turkey (46). Disease symptoms include formation of small papillae or projections in the leaf underside (Fig. 1A) and the corresponding indentations in the upper side at scattered locations on leaf veins of Mexican lime (C. aurantifolia (Christm.) Swing), sour orange, and to a lesser degree in other host species (64), and galls on the trunk and branches of Mexican and Rangpur (C. limonia Osb.) limes, rough lemon, and $C$. volkameriana Ten. and Pasq. (Fig. 1B). The putative vein enation pathogen is transmitted by several aphid species, including T. citricida, T. aurantii (Boyer de Fonscolombe), Aphis gossypii (Glover), and Myzus persicae (Sulz.) $(29,34,40,64)$ in a persistent mode, at least in the last two species (25). Isometric virus-like particles of approximately $28 \mathrm{~nm}$

Corresponding author: M. C. Vives; E-mail address: cvives@ivia.es

* The $\boldsymbol{e}$-Xtra logo stands for "electronic extra" and indicates that the online version contains two supplemental figures and one supplemental table. Figure 1 appears in color online.

http://dx.doi.org/10.1094/PHYTO-03-13-0068-R

(C) 2013 The American Phytopathological Society in diameter were observed by electron microscopy in phloem cells from vein outgrowths and in the salivary glands of infectious aphids, and four weak dsRNA bands ranging from $\approx 3.6 \times 10^{6}$ to $\approx 0.5 \times 10^{6}$ molecular mass were detected in bark extracts from infected plants, suggesting that a luteovirus might be the causal agent of vein enation $(4,33)$. Moreover, positive enzyme-linked immunosorbent assay (ELISA) reaction was obtained for a South African vein enation isolate using a commercial antiserum to Barley yellow dwarf virus (3). However, attempts to purify the putative viral agent associated to vein enation or to amplify cDNA using luteovirus-specific primers were unsuccessful (unpublished data); therefore, the luteovirus hypothesis remained unconfirmed.

Control of virus diseases by inoculum exclusion, eradication or development of resistant cultivars needs quick and reliable diagnostic methods. Up to now vein enation could be diagnosed only by biological indexing on sensitive indicator plants, usually young seedlings of Mexican lime, grown in a temperature-controlled insect-proof glasshouse at a relatively low temperature (18 to $26^{\circ} \mathrm{C}$ ) (52). Leaf symptoms usually appears 2 to 6 months after inoculation and vein projections incited by some isolates are so scarce and tiny that they can be reliably detected only by well trained personnel. Therefore, biological indexing of this disease is slow, expensive, and it cannot be used for massive field indexing. Since the disease is aphid transmitted, all budwood source plants used for nursery plant propagation under the Spanish citrus certification program have to be indexed for vein enation every 1 to 2 years, becoming a major constraint for the certification program.

Plants and other eukaryotes have developed a defense mechanism against virus infection based on posttranscriptional gene silencing. This mechanism involves the production of virus-derived small RNAs (vsRNAs) of 21 to 25 nucleotides (nt) that upon incorporation in a RNA silencing complex (RISC) guide 
sequence-specific degradation of the genomic RNA (gRNA) thus limiting virus accumulation (reviewed in Ding and Voinnet [9]).

The advent of next generation high-throughput sequencing platforms has opened the possibility of random sequencing sRNA samples from diseased tissues to identify the pathogens associated with symptoms (50). This methodology does not require any prior genomic knowledge for the construction and sequencing of the cDNA libraries and it allows identification of viral RNA or DNA genomes in a single analysis. Deep sequencing of sRNAs and comparison of the sequences obtained with those available in public databases enabled identification of unknown virus and viroids present in plants and insects $(20,28,32,47,68,71)$.

In this study we applied deep sequencing of sRNAs to identify a new virus, provisionally named Citrus vein enation virus (CVEV), associated with citrus vein enation disease. This virus is phylogenetically related to Pea enation mosaic virus (PEMV-1). Based on the sequence obtained, digoxigenin (DIG)-labeled cDNA probes were prepared and primers designed for CVEV detection by hybridization or reverse transcription-polymerase chain reaction (RT-PCR), respectively. The CVEV vsRNA population was characterized in terms of size and polarity class frequencies and distribution along the viral genome.

\section{MATERIALS AND METHODS}

Virus source and plant material. The VE-1 isolate used in this work was originally obtained from a field tree of Washington navel sweet orange (C. sinensis (L.) Osb.) grafted on $C$. volkameriana showing woody gall symptoms in Castellón, Spain. This tree had been planted virus-free and became naturally infected with vein enation disease, but it remained free of other known viruses and viroids. The VE-1 isolate was maintained in plants of Mexican lime grown in an artificial potting mix $(50 \%$ sand and $50 \%$ peat moss) in a temperature-controlled (18 to $26^{\circ} \mathrm{C}$ ) greenhouse and fertilized by a standard procedure (2). The virus was graft inoculated to Etrog citron $(C$. medica L.) plants and infection was confirmed by indexing on Mexican lime plants.

A rough lemon seedling showing vein enation-woody gall symptoms, field trees of Valencia late sweet orange, Nova mandarin $(C$. clementina Hort. ex Tan. $\times(C$. paradisi Macf. $\times C$. tangerina Hort. ex Tan.)), Ortanique tangor $(C$. reticulata Blanco $\times$ C. sinensis), and Owari satsuma (C. unshiu (Mak.) Marc.) grafted
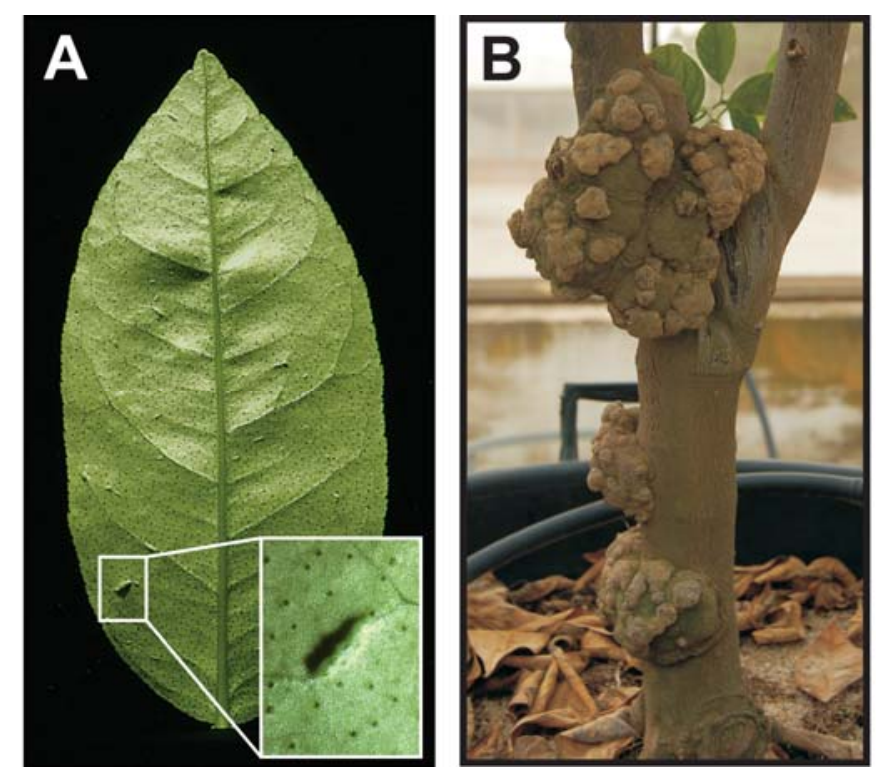

Fig. 1. Specific symptoms of citrus vein enation disease. A, Enations on Mexican lime leaf veins. B, Woody galls on the trunk of Citrus volkameriana. on Carrizo citrange (C. sinensis $\times$ Poncirus trifoliata (L.) Raf.), and Mexican lime seedlings noninoculated or inoculated with the VE-1 isolate were used to test the new CVEV molecular detection techniques. All sources were indexed on Mexican lime plants to confirm vein enation infection.

Nucleic acid extraction and sequencing. Total RNA (RNAt) was isolated from $2 \mathrm{~g}$ of fresh bark from healthy $(\mathrm{H})$ and vein enation-infected (VE) Etrog citron plants using TRIzol (Invitrogen, Carlsbad, CA) following the manufacturer's indications. To obtain sRNA-enriched preparations, RNAt from $\mathrm{H}$ and VE citron bark tissue $(250 \mathrm{mg})$ was extracted with TRI-Reagent and 1-bromo-3-chloro-propane (Sigma-Aldrich, St. Louis), precipitated with isopropanol and resuspended in $150 \mu \mathrm{l}$ of RNase-free water. High-molecular mass RNAs were precipitated with $1 \mathrm{M}$ $\mathrm{NaCl}$ and $10 \%$ polyethylene glycol (PEG 8000), and the sRNAs were ethanol precipitated and resuspended in $25 \mu \mathrm{l}$ of RNase-free water (69). The amount and quality of the RNA were checked using a spectrophotometer (Nanodrop, Thermo Fisher Scientific, Wilmington, DE) and agarose gel electrophoresis.

The sRNA fraction from $\mathrm{H}$ and VE citron samples were used to generate cDNA libraries as previously described (28). Both libraries were sequenced as $50 \mathrm{nt}$ single reads on a single lane of the Illumina Genome Analyzer Hi-Seq2000 (FASTERIS SA, Plan-les-Ouates, Switzerland). Gaps between contigs assembled from the VE library showing sequence homology with viral genomes were filled by RT-PCR amplification (62) using RNAt from inoculated citron plants and specific primers (Table 1) designed from the terminal sequences of those contigs (Fig. 2). Clones of the $5^{\prime}$ and $3^{\prime}$ termini were obtained using the $5^{\prime} / 3^{\prime}$ RACE Kit (Roche Applied Science, Mannheim, Germany) following the manufacturer's instructions and specific primers (Table 1). The RT-PCR products were examined in a $1 \%$ agarose gel, and those with the expected size were cloned in pGEM-T plasmid (Promega, Madison, WI) using standard protocols (55). The nucleotide sequence of the inserts was determined with an ABI PRISM 3100 Genetic Analyzer (Applied Biosystems, Carlsbad, CA) using primers derived from the plasmid or from the CVEV sequence for internal regions of the largest cDNA clones (Table 1). The sequence of all gRNA regions was obtained from at least three different clones.

Bioinformatic analysis. Reads from the deep sequencing output of the VE and $\mathrm{H}$ libraries were trimmed to remove adaptors, ribosomal and transfer RNA sequences by using the BWA tool $0.5 .8 \mathrm{c}$ (30), and sRNAs of 18 to $26 \mathrm{nt}$ were selected to build the profile of reads. Sequences that were $100 \%$ identical were grouped and only one representative was considered. The inserts of the $\mathrm{H}$ library were assembled using VELVET 1.0.13 (70) and OASES 0.1.16 (56) software and the inserts of the VE library were independently mapped with the BWA tool on the transcript assembly of the $\mathrm{H}$ library corresponding to the hash 19 . The VE inserts not mapped on the contigs of the H library were selected and assembled de novo into larger contigs using VELVET software with a $17 \mathrm{k}$-mer value. To find similar known sequences, the basic local alignment search tool tBLASTx (1) with an e-value cut-off of $10^{-4}$ were used to query contig sequences against the GeneBank nonredundant (nr) database in NCBI (http://www.ncbi. nlm.nih.gov). In order to eliminate plant sequences, the VE contigs were also mapped on the available $C$. sinensis and $C$. clementina genome sequences with tBLASTx in Phytozome v8.0 web (http://www.phytozome.net) (22). Viral sequences were identified based on the BLAST results and used to obtain the complete gRNA sequence of CVEV. Standard sequence analyses of the new virus genome were done using the software available at the NCBI website (Open Reading Frame Finder and Conserved Domain Search Service). The RNA secondary structure of minimum energy was predicted with the MFOLD program, version 3.5, at the MFOLD website http://mfold.rit.albany.edu/?q=mfold/RNAFolding-Form (73). 
To obtain the profile distribution of CVEV vsRNAs, the 18 to $26 \mathrm{nt}$ reads of the VE library were aligned on the assembled CVEV genomic sequence using the Biostrings 2.20.1 software (http://www.bioconductor.org) and the output file was visualized with the R statistical software (http://www.r-project.org).

Phylogenetic analyses were done using the amino acid sequences encoded by ORFs 2 and 3, containing motifs conserved in the RNA-dependent RNA polymerase (POL) and coat protein (CP) of different luteoviruses, respectively. The following viral sequences showing similarities with the CVEV sequence in the database search, were used for comparison: Pea enation mosaic virus-1 (PEMV-1.1, HM439775; PEMV-1.2, L04573) enamovirus; Barley yellow dwarf virus (BYDV1, AF218798; BYDV6, AY610953; BYDV17, EF521847), Bean leafroll virus (BLRV, AF441393), Rose spring dwarf-associated virus (RSDaV1, NC_010806; RSDaV2, EU024678), and Soybean dwarf virus (SbDV2, DQ145545; SbDV3, AB076038; SbDV8, AB038147) luteoviruses; and Beet chlorosis virus (BChV1, AF352025; BChV2, AF352024), Beet eastern yellows virus (BEYV1, EU636991; BEYV2, EU636990), Beet mild yellowing virus (BMYV1, DQ132996; BMYV2, NC_003491), Beet western yellows virus (BWYV1, HM804471; BWYV3, AF473561), Cucurbit aphid-borne yellows virus (CABYV1, EU636992; CABYV2, EU000535), Cotton leafroll dwarf virus (CLRDV1, HQ827780; CLRDV3, GU167940), Chickpea chlorotic stunt virus (CpCSV, NC_008249), Carrot red leaf virus (CtRLV, AY695933), Cereal yellow dwarf virus (CYDV1, L25299; CYDV2, AF235168), Melon aphid-borne yellows virus (MABYV, NC_010809), Potato leafroll virus (PLRV1, AF453394; PLRV3, AF453392), Pepper vein yellows virus (PVYV, NC_015050), Sugarcane yellow leaf virus (ScYLV1, AF157029; ScYLV7, GU327735), Tobacco vein distorting virus (TVDV, NC_010732), Turnip yellows virus (TuYV, NC_003743), and Wheat yellow dwarf virus (WYDV, FM865413) poleroviruses. Multiple alignments of amino acid sequences were done with CLUSTAL W (61). Phylogenetic trees were constructed by the neighbor-joining method using MEGA version 5 (60) and the statistical significance of branch order was estimated by 1,000 replications bootstrap resampling from the original alignments.

CVEV RNA detection. For RT-PCR detection, two primer sets (Table 1) were designed based on the assembled gRNA sequence: Primers VE5f and VE15r, encompassing the POL conserved domains within ORF 2, and primers VE16f and VE17r, located in the $5^{\prime}$-terminal region of the coat protein gene (CP), ORF 3. For cDNA synthesis, $1 \mu \mathrm{l}$ of RNAt, equivalent to $4 \mathrm{mg}$ of plant tissue, and $0.2 \mu \mathrm{M}$ of each primer were denatured at $85^{\circ} \mathrm{C}$ for $5 \mathrm{~min}$ and chilled on ice. Then, one-step RT-PCR was performed in a $25-\mu 1$ reaction volume containing $1 \times \mathrm{PCR}$ buffer $(20 \mathrm{mM}$ Tris- $\mathrm{HCl}, \mathrm{pH}$ $8.4,50 \mathrm{mM} \mathrm{KCl}$ ), $3 \mathrm{mM} \mathrm{MgCl} 2,0.4 \mathrm{mM}$ dNTPs, 4 units of Rnase OUT ribonuclease inhibitor, 20 units of SuperScript II reverse transcriptase and 1 unit Taq DNA polymerase (Invitrogen). After incubation at $42^{\circ} \mathrm{C}$ for $45 \mathrm{~min}$ for RT and enzyme inactivation at $94^{\circ} \mathrm{C}$ for $2 \mathrm{~min}$, thermocycling conditions were as follows: 40 cycles of $20 \mathrm{~s}$ at $94^{\circ} \mathrm{C}, 20 \mathrm{~s}$ at $65^{\circ} \mathrm{C}$ and $20 \mathrm{~s}$ at $72^{\circ} \mathrm{C}$, followed by a final extension of $5 \mathrm{~min}$ at $72^{\circ} \mathrm{C}$. The PCR products were separated by electrophoresis in $2 \%$ agarose gels in $1 \times$ TAE buffer (40 mM Tris-acetate, $\mathrm{pH} 8.3,1 \mathrm{mM}$ EDTA) and visualized on a UV-transilluminator after GelRed (Biotium, Hayward, CA) staining. Amplicons of the expected size were purified and sequenced.

In order to prepare CVEV-specific probes, the cDNA of the POL, CP, hotspot for vsRNAs (HS), and low coverage of vsRNAs (LC) regions were obtained by RT-PCR using specific primers (Table 1) and cloned in the pGEM-T plasmid vector. cDNA probes of POL and CP clones were synthesized using the corresponding primers and the PCR DIG-labeling and detection kit (Roche Applied Science). DIG-labeled RNA transcripts of the (-) polarity were synthesized from the HS and LC cDNA clones by incorporation of DIG-UTP using T7 RNA polymerase according to the manufacturer's instructions (Roche Applied Science).

For dot blot hybridization $1 \mu \mathrm{l}$ of RNAt was denatured at $94^{\circ} \mathrm{C}$ for $5 \mathrm{~min}$ in $50 \%$ formamide, chilled on ice, and then spotted onto positively charged nylon membranes (Roche Applied Science). For Northern blot analysis of CVEV RNAs, $3 \mu \mathrm{g}$ of RNAt was denatured at $94^{\circ} \mathrm{C}$ for $5 \mathrm{~min}$ in $50 \%$ formamide, chilled on ice, separated by electrophoresis in formamide-formaldehyde denaturing $1.2 \%$ agarose gels in MOPS buffer, and electroblotted onto positively charged nylon membranes (Roche Applied Science) at $250 \mathrm{~mA}$ for $1 \mathrm{~h}$ and $1 \mathrm{~A}$ for $15 \mathrm{~h}$, using $25 \mathrm{mM}$ phosphate buffer, $\mathrm{pH}$ 6.45. To analyze CVEV-derived sRNAs, $6 \mu \mathrm{g}$ of sRNAs was mixed with an equal volume of formamide, heated at $94^{\circ} \mathrm{C}$ for $5 \mathrm{~min}$, and separated in a $15 \%$ polyacrylamide Tris-borate-EDTA (TBE)-urea gel. sRNAs were then electroblotted onto positively charged nylon membranes (Roche Applied Science) at $25 \mathrm{~V}$ for $1 \mathrm{~h}$ using TBE buffer. After UV cross-linking, membranes were hybridized at $60^{\circ} \mathrm{C}$ (for CVEV gRNA and sgRNA) or $42^{\circ} \mathrm{C}$ (for sRNAs) and washed according to Galipienso et al. (18). Hybri-

TABLE 1. Specific Citrus vein enation virus primers used in this work

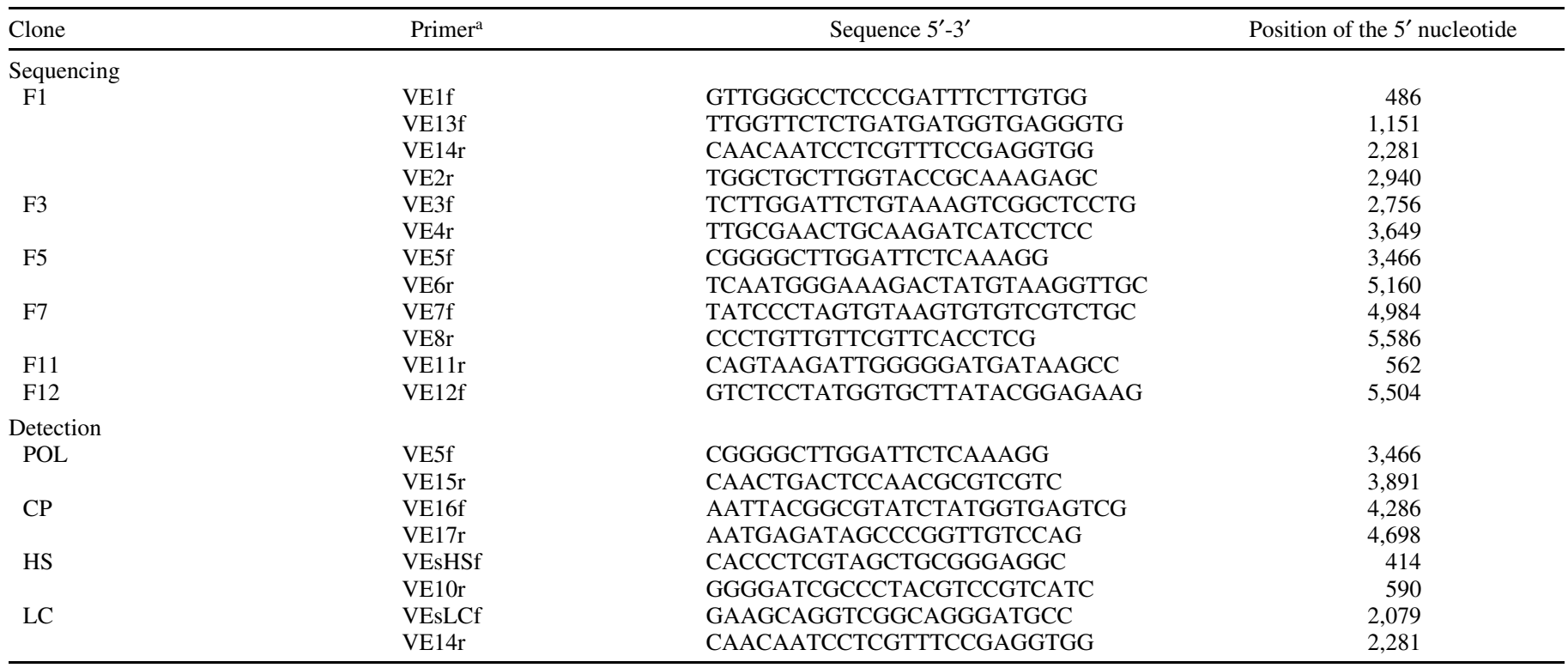

${ }^{a}$ f, forward; r, reverse. 
dization reactions were developed using CDP-Star chemiluminescent substrate (Roche Applied Science) and visualized with the Luminescent Image Analyzer LAS-3000 (Fuji Photo Film (Europe), Düsseldorf, Germany) or with X-ray films (Care-stream Health Inc., Rochester, NY).

\section{RESULTS}

Identification of viral sequences by high-throughput sequencing of sRNAs from vein enation-infected plants. In order to identify potential pathogens associated with vein enation (VE) disease, two cDNA libraries from healthy $(\mathrm{H})$ and inoculated (VE) Etrog citron plants were constructed and sequenced on the Illumina Genome Analyzer SN365-Hi-Seq2000 (FASTERIS SA, Plan-les-Ouates, Switzerland) as previously reported (10). The H library was constructed in order to eliminate citrus-derived sequences from the VE library. Library $\mathrm{H}$ contained a total of 34.74 million raw short reads. After removal of adapters, size selection of 18 to $26 \mathrm{nt}$ reads and filtering for transfer and ribosomal RNAs, a data set of 22.96 million reads was obtained and subjected to the novo assembly, generating a total of 1,365 contigs.

The 12.19 million filtered reads obtained from the VE library were mapped on the contigs obtained from the $\mathrm{H}$ library thus allowing elimination of $23.8 \%$ of the sequences belonging to the host. The remaining 9.29 million reads from the VE library were subjected to the novo assembly, which produced 155 contigs ranging from 35 to $211 \mathrm{nt}$. These contigs were analyzed by tBLASTx searching against the NCBI nonredundant (nr) database and also against the $C$. sinensis and $C$. clementina genome sequences already available at Phytozome web. While 136 contigs showed amino acid (aa) similarity with different citrus genes and 10 contigs did not show similarity with any sequence available in databases, 9 contigs showed amino acid similarity with genes encoded by different members of the family Luteoviridae, being more similar to PEMV-1 enamovirus.

Complete sequence, genome organization, and phylogenetic relationships of CVEV. The nine contigs showing similarity with luteoviruses were mapped on the PEMV-1 gRNA (Fig. 2A, black lines) and then used to design primer pairs specific for the new viral sequence (Table 1). Overlapping PCR products covering the entire gRNA were obtained (Fig. 2B) and assembled in a fullgenome sequence of 5,983 nt. The nucleotide sequence of all gRNA regions was obtained from at least three different clones with mismatches representing about $0.8 \%$ of the whole genome. After assembling the entire genome sequence, the 10 contigs that had not shown similarity with sequences available in databases were mapped on the CVEV gRNA and all of them matched with the new sequence (Fig. 2A, gray lines). Thus, the contigs assembled from the sRNA reads covered about $46.38 \%$ of the gRNA. The complete nucleotide sequence of the CVEV isolate VE-1 is available at the European Nucleotide Archive (http://www.ebi.ac. uk/ena/data/view/HF679486).

Reading frame analysis showed that the CVEV gRNA has five potential open reading frames (ORFs) in its positive-sense strand, with two untranslated regions (UTR) of 207 and $198 \mathrm{nt}$ at the $5^{\prime}$ and $3^{\prime}$ termini, respectively, and an intergenic region (IR) of 122 nt between ORFs 2 and 3 (Fig. 2C). No ORF of significant size was found in the negative-sense strand.

ORF 0 (nt 219 to 1,283) potentially encodes a 39-kDa polypeptide of 354 aa (Fig. 2C). It overlaps completely with ORF 1 and the context of its start codon is consistent with the Kozak's leaky scanning translational model (27). Nucleotide and amino acid sequence comparison with the homologous PEMV-1 ORF 0 showed 48.0 and $37.6 \%$ similarity, respectively. The cognate products of polero- and enamoviruses are RNA silencing suppressors and their mode of action is conserved despite their low sequence similarity $(17,48)$.

ORF 1 (nt 208 to 2,916 ) potentially encodes a 100-kDa protein of 902 aa containing a conserved serin proteinase domain characteristic of the S39 peptidase superfamily followed by the genomelinked viral protein $(\mathrm{VPg})$ present in enamo- and poleroviruses. Nucleotide and amino acid comparison with the homologous PEMV-1 ORF 1 showed 48.4 and $45.1 \%$ similarity, respectively. The proposed $\mathrm{H}(\mathrm{x}-29) \mathrm{D}(\mathrm{x}-65) \mathrm{GxSG}$ active site residues of the

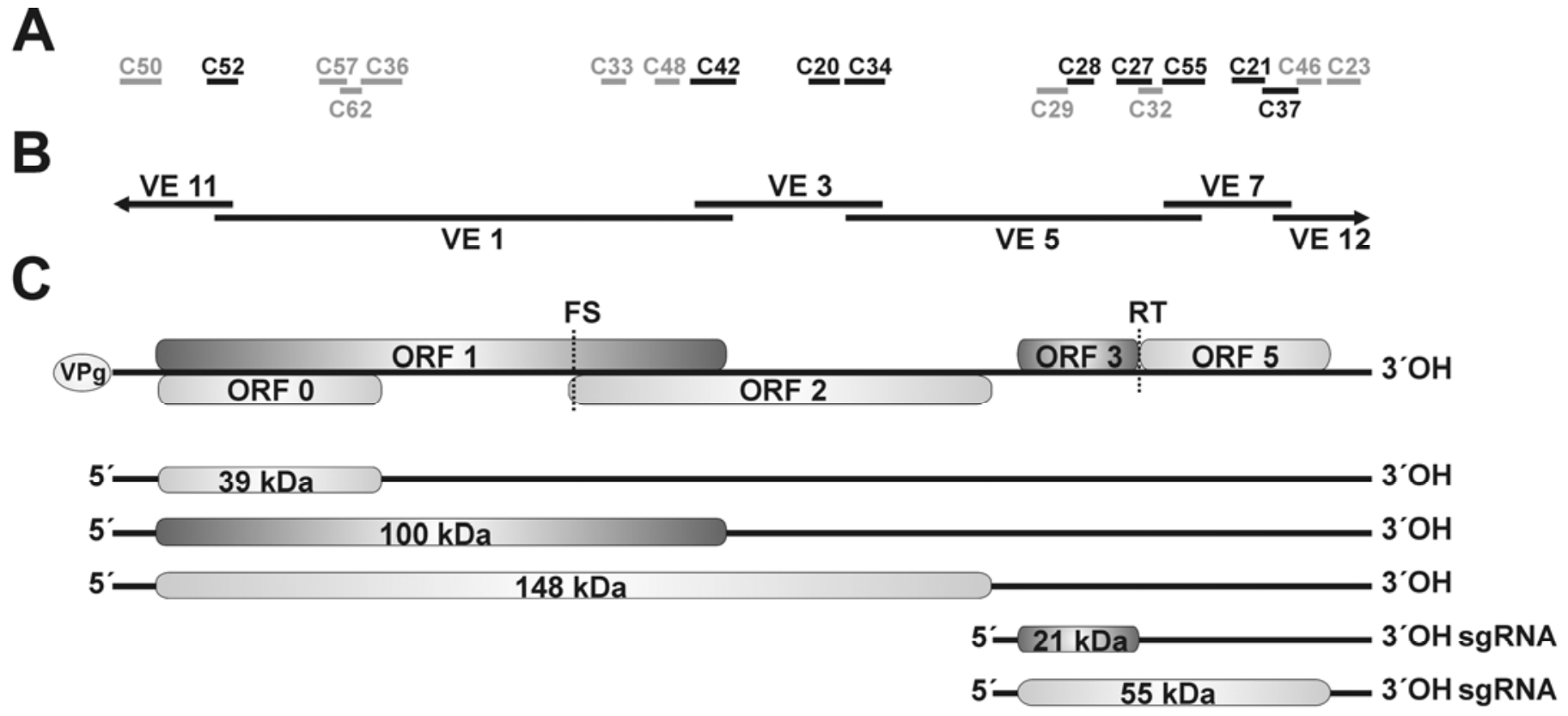

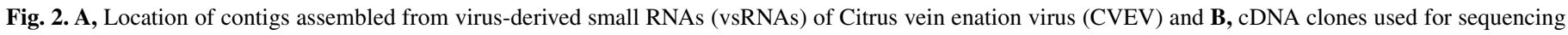

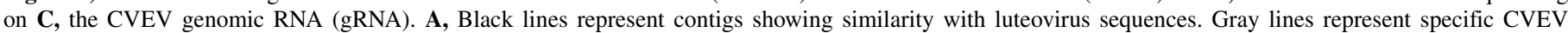

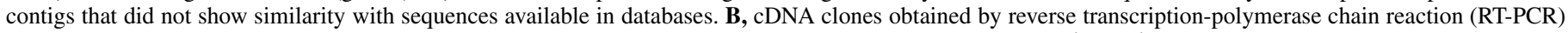

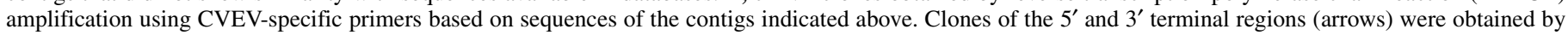

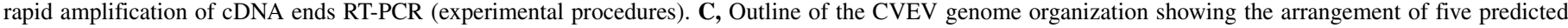

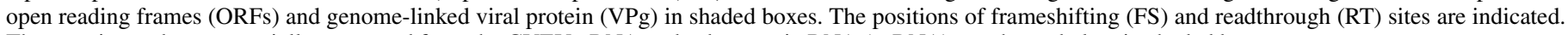
The protein products potentially expressed from the CVEV gRNA and subgenomic RNA (sgRNA) are shown below in shaded boxes. 
serin proteinase domain (31) encoded by ORF 1 is located between nucleotide positions 1,459 and 1,758 of the gRNA. Although the region encoding the VPg is similarly located in the genomes of enamo-, polero- and sobemoviruses, no significant amino acid similarity was found in this region between CVEV and these viruses; however, the conserved $(\mathrm{Q}, \mathrm{E}) /(\mathrm{G}, \mathrm{S}, \mathrm{A})$ cleavage sites presumed to release the VPg in those genera (23) are located between positions 1,912 and 2,007 in the CVEV gRNA. Moreover, the conserved W(A/G)D amino acid sequence followed by a D/E-rich domain present in enamo-, polero-, and sobemoviruses (36) is located between positions 2,119 and 2,157 in the CVEV gRNA. This amino acid motif of unknown function, located upstream of a putative -1 frameshift signal, has been suggested to be part of the VPg of these viruses (35).

ORF 2 (nt 2,202 to 4,187) is translated by a -1 ribosomal frameshift from ORF 1 and it encodes a 148-kDa fusion protein of 1,323 aa (Fig. 2C) that contains helicase and POL domains harboring the consensus GDD core motif conserved in the family Luteoviridae $(6,24,39)$. Nucleotide and amino acid sequence comparison with the homologous PEMV-1 ORF 2 showed 57.6\% and $63.7 \%$ similarity, respectively. Ribosomal frameshifting has been described in many positive-stranded RNA viruses including luteoviruses, and it has been reported to require two mRNAencoded signals: a heptanucleotide at which the shift occurs and a pseudoknot or a very stable RNA stem-loop located six to eight nucleotides downstream of the heptanucleotide $(21,37,42,43)$. Computer analysis of the CVEV gRNA showed the presence of the heptanucleotide TTTAAAC (nt 2,202 to 2,208) and MFOLD analysis of surrounding regions revealed a predicted stem-loop secondary structure of minimum energy located eight nucleotides downstream of the heptanucleotide. Both elements could be the frameshifting signal in the CVEV genome.

ORF 3 (nt 4,301 to 4,876) encodes a 21-kDa protein of 191 aa identified as the putative CP. Nucleotide and amino acid comparisons with the PEMV-1 CP showed 51.7 and 54.5\% similarity, respectively.

ORF 5 (nt 4,877 to 5,785) is expressed by readthrough the CP amber stop codon as a 55-kDa fusion protein of 493 aa (Fig. 2C).

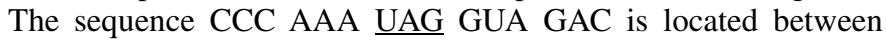
positions 4,868 and 4,879 in the CVEV gRNA and it is followed by a series of seven tandem repeats of the motif CCN NNN beginning 24 bases downstream of the $\mathrm{CP}$ stop codon. Both elements are readthrough motifs conserved in luteoviruses (42). Nucleotide and amino acid comparison with the homologous PEMV-1 ORF 5 showed 56.6 and $62.0 \%$ similarity, respectively. In other luteoviruses, this protein is involved in symptom expression, virus accumulation, and likely in systemic spread. It plays also a key role in transmission efficiency and specificity and in virus persistence within the aphid vector (reviewed in Stevens et al. [58]).

Northern blot analysis of RNAt from CVEV-infected Etrog citron plants using cDNA probes specific for the POL and $\mathrm{CP}$ genomic regions consistently detected an $\approx 6.0-\mathrm{kb}$ RNA molecule hybridizing with both probes and an $\approx 1.7-\mathrm{kb}$ RNA molecule hybridizing only with the $\mathrm{CP}$ probe (Fig. 3). While the first is likely the CVEV gRNA, the second may be a subgenomic (sg) messenger RNA involved in expression of the ORFs 3 and 5. It has been reported that in luteoviruses the gRNA and sgRNA contain a similar 8- to 10 -nt sequence at their $5^{\prime}$ termini (42). In $\mathrm{CVEV}$, the sequence ATA(T/A)AA(G/T)CTATAA is present at the $5^{\prime}$ end of the gRNA and in the intergenic region between ORFs 2 and 3 (nt 4,271 to 4,284).

In phylogenetic analyses of the amino acid sequences of the POL (Fig. 4A) and CP (Fig. 4B) domains conserved in enamo-, luteo-, and poleroviruses, CVEV consistently clustered with viruses in the genus Enamovirus.

Characterization of the CVEV-derived sRNAs. To characterize the vsRNAs produced during CVEV infection, the sRNAs used for deep sequencing were analyzed with Biostrings software. As indicated above, about 12.19 million total reads were obtained from the VE library. Reads ranging from 18 to $26 \mathrm{nt}$ were mapped on the viral gRNA built up in this work in sense and antisense orientation and only sequences showing absence of mismatches with the reference sequence were considered vsRNAs and used for further analyses. The library contained 1,731,600 perfectly matched CVEV vsRNAs representing $14.21 \%$ of the total sRNA population. The prevalent vsRNA size class was $21 \mathrm{nt}(751,208$ reads, corresponding to $43.38 \%$ of the total vsRNAs) followed by the 24-nt species (434,009 reads, corresponding to $25.06 \%$ of the total vsRNAs) and 22-nt species (190,785 reads, corresponding to $11.02 \%$ of the total vsRNAs). Furthermore, analysis of the vsRNA polarity showed a clear prevalence of those derived from the messenger sense $(+)$ strand $(1,196,267$ reads, corresponding to $69 \%$ of the total vsRNAs) (Supplemental Table 1).

Analysis of the $5^{\prime}$ nucleotide in the vsRNAs showed prevalence of $\mathrm{U}$ in the 21 -nt size class $(76.7 \%)$ and $\mathrm{A}$ in $22-$ to $24-\mathrm{nt}$ size groups (33.9, 38.3, and $41.0 \%$, respectively) (Fig. 5A). When polarity of the vsRNAs was taken into consideration, $U$ and A were confirmed as the most frequent residues at the $5^{\prime}$ terminal position of both (+) and (-) vsRNAs in all size classes (Fig. 5B and C).

Distribution of the 18- to 26-nt vsRNA sequences of both polarities along the CVEV gRNA was also determined (Supplemental Figure 1). While the vsRNAs identified spanned the entire genomic sequence, the 19 contigs assembled from those vsRNAs only covered $46.38 \%$ of the genome length, possibly because overlaps between vsRNAs were shorter than the defined k-mer value (17 nucleotides) in the Velvet program. Distribution of CVEV vsRNAs along the genome was uneven, with the presence of a major hotspot for the (+) 21-nt class located in the $5^{\prime}$ proximal region between positions 530 and 552 of the gRNA, and three minor hotspots of $(+)$ and $(-)$ polarities located in ORFs 3 and 5. The presence of the major hotspot was confirmed by northern blot analysis of the sRNAs purified from CVEV-infected Etrog citron plants. While hybridization with the riboprobe LC, complementary to genomic positions 2,079 to 2,281 (with a low coverage of vsRNAs), failed to provide any signal, hybridization with the riboprobe HS, complementary to genomic positions 414 to 590 (with a high coverage of sRNAs), generated a clear signal corresponding to 21-nt vsRNAs only in CVEV-infected citron plants (Supplemental Figure 2).

Detection of CVEV in infected plants by molecular hybridization and RT-PCR. Availability of the CVEV sequence

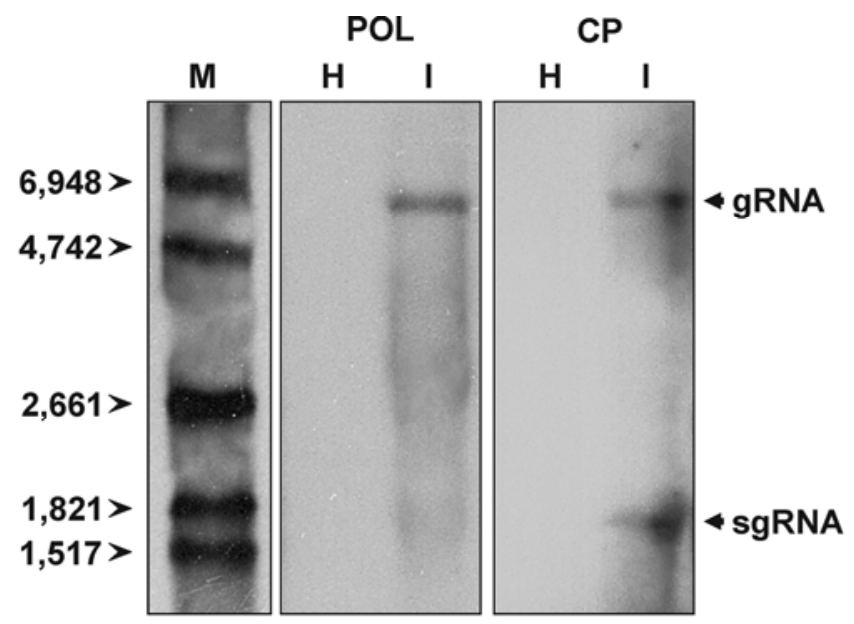

Fig. 3. Northern blot analysis of total RNA extracted from Citrus vein enation virus-infected $(\mathrm{I})$ or healthy $(\mathrm{H})$ Etrog citron plants. Membranes were hybridized using the digoxigenin-labeled cDNA probes POL and CP, corresponding to genomic regions within open reading frames (ORFs) 2 and 3 , respectively. Arrowheads show the positions of the genomic RNA (gRNA) and the subgenomic RNA (sgRNA). Sizes (bp) of marker RNAs (M) are to the left. 
allowed testing the association of vein enation disease with the presence of the virus. For this purpose, field trees of different citrus varieties were indexed for vein enation by graft-inoculation on the sensitive indicator host Mexican lime and analyzed by RTPCR and dot-blot hybridization with CVEV-specific primers (Table 1) or cDNA probes, respectively. Mexican lime plants uninoculated or inoculated with the CVEV isolate VE-1 were used as negative and positive control, respectively. RT-PCR amplification using RNAt and primers VE5f and VE15r or VE16f and VE17r, yielded single DNA bands of 425 and 413 bp, respectively, with all plant samples inducing vein enation on Mexican lime, whereas no amplification was obtained with equivalent RNAt extracts from vein enation-free plants (Fig. 6A and data not shown). Sequencing confirmed that the POL and CP fragments PCR amplified from the positive control shared $100 \%$ nucleotide sequence identity with the newly assembled gRNA sequence (data not shown). Similarly, hybridization signals of variable intensity were obtained by dot-blot using the POL and CP cDNA probes and the same RNAt extracts from vein enation-inducing plants, but no hybridization signal was observed with vein enation-free plant extracts (Fig. 6B and data not shown).

\section{DISCUSSION}

Deep sequencing of sRNAs extracted from an Etrog citron infected with citrus vein enation disease allowed identification of a novel virus provisionally named Citrus vein enation virus (CVEV). BLAST search in nucleotide and protein databases successfully identified several contigs showing similarity with members of the family Luteoviridae, particularly with PEMV-1, thus confirming initial suggestions that vein enation disease might be associated with a luteovirus (4,33). Presently this family comprises three genera, Luteovirus, Polerovirus, and Enamovirus, differing in genome organization. The key features that distinguish the genus Enamovirus from the other two genera are as follows: (i) while the gRNA in luteo- and poleroviruses has six ORFs, in the genus Enamovirus it has only five, with ORF 4 lacking in this latter genus, (ii) the genus Enamovirus has a VPg linked to the $5^{\prime}$ terminus of its gRNA and possess an ORF 0 (both absent in luteoviruses albeit present in poleroviruses), (iii) as with poleroviruses, the non-coding intergenic region between ORFs 2 and 3 has about $200 \mathrm{nt}$ in the genus Enamovirus but only $100 \mathrm{nt}$ in genus Luteovirus, (iv) also similar to poleroviruses, the ORFs 1 and 2 overlap by more than $400 \mathrm{nt}$ in the genus Enamovirus and the frameshift between these ORFs occurs upstream of the termination of ORF 1, whereas in luteoviruses the ORFs 1 and 2 overlap in less than $20 \mathrm{nt}$ and the frameshift occurs at the termination codon of the ORF 1 , and (v) the ORF 5 in the genus Enamovirus is about $900 \mathrm{nt}$, clearly smaller than luteoviruses (more than 1,350 nt) and poleroviruses (more than 1,200 nt) (11). The arrangement of the five ORFs predicted in the CVEV genome fits all key features of the genus Enamovirus, except for the

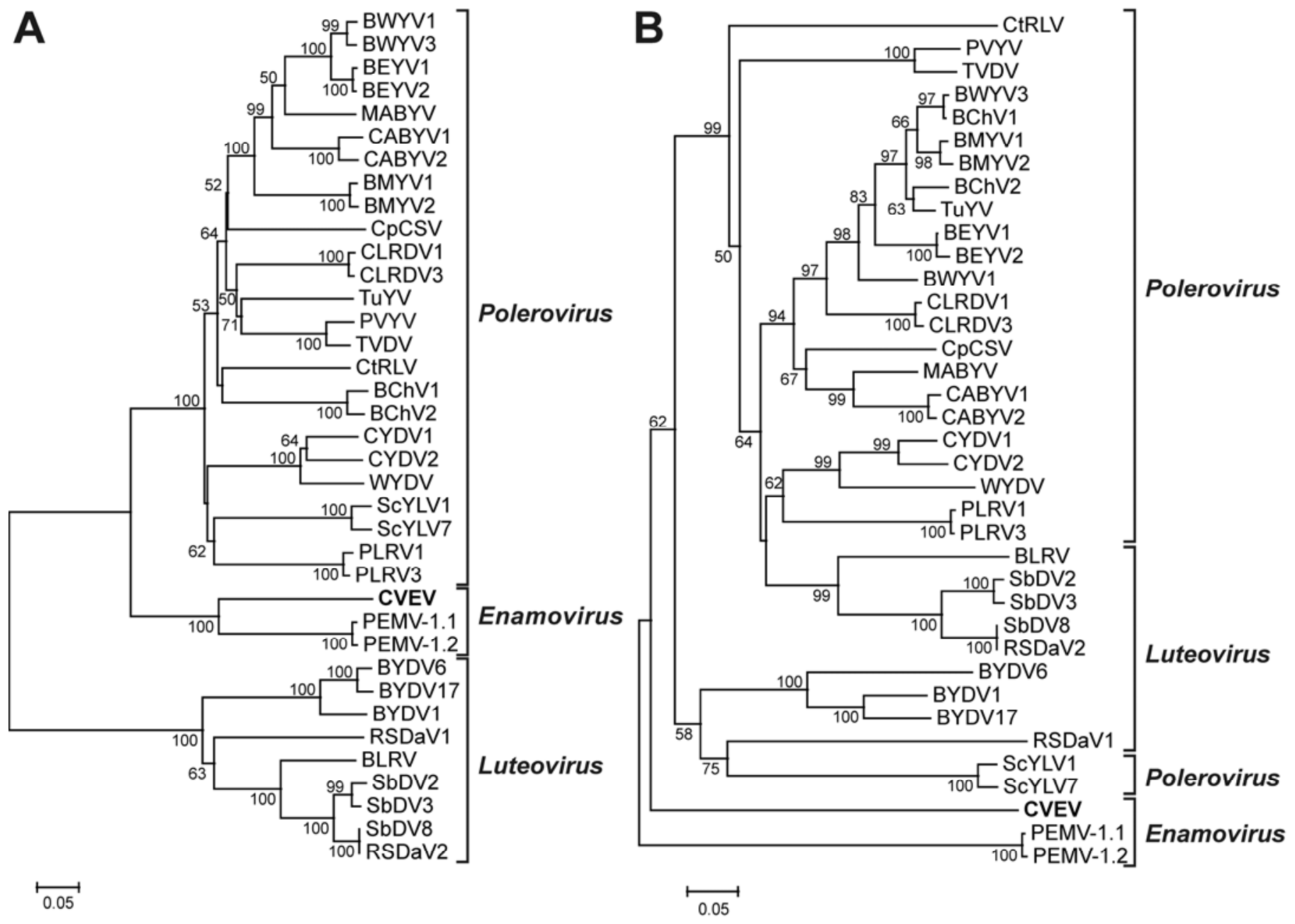

Fig. 4. Phylogenetic analysis of amino acid signatures in A, RNA-dependent RNA polymerase (POL) and $\mathbf{B}$, coat protein $(\mathrm{CP})$ domains of Citrus vein enation virus (CVEV) and members of the genera Enamovirus (PEMV-1), Luteovirus (BLRV, BYDV, RSDaV, and SbDV), and Polerovirus (BChV, BEYV, BMYV, BWYV, CABYV, CLRDV, CpCSV, CtRLV, CYDV, MABYV, PLRV, PVYV, ScYLV, TVDV, TuYV, and WYDV). Trees were constructed by the neighbor-joining method using amino acid sequences aligned with the CLUSTAL W program and significance of the nodes based on 1.000 bootstrap replicates is indicated. Branch length is proportional to the number of amino acid changes. 
size of the intergenic region between ORFs 2 and 3 (122 nt) that is smaller than in PEMV-1 and poleroviruses and closer to that found in luteoviruses. As in other members of the family Luteoviridae, northern blot analyses of RNAt from CVEV-infected plants detected, in addition to the gRNA, an sgRNA that might be involved in expression of the ORFs 3 and 5. Therefore, while ORFs 0,1 , and 2 of CVEV could be translated directly from the gRNA, ORFs 3 and 5 would be expressed via the synthesis of a $3^{\prime}$ co-terminal sgRNA. There is no direct evidence on the mechanism of sgRNA synthesis in luteoviruses, but it is thought that the viral POL initiates sgRNA transcription at internal promoter sites on the minus gRNA strand synthesized during replication (reviewed in Miller et al. [42] and Stevens et al. [58]). Altogether, the genome organization and expression and phylogenetic relationships with other members of the family Luteoviridae support the inclusion of CVEV in the genus Enamovirus. This is the second enamovirus sequenced and the first found infecting a woody plant. Although Koch's postulates have not yet been fulfilled and therefore we cannot affirm that the new virus is re-

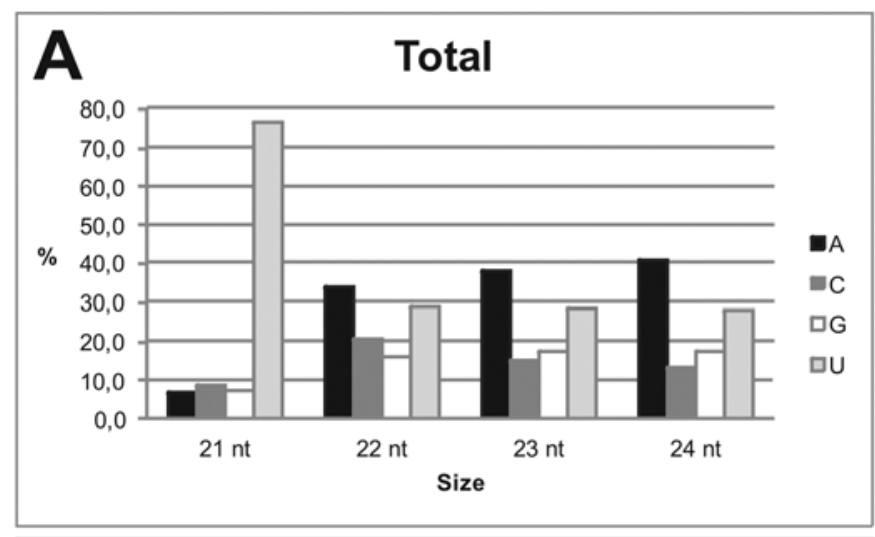

\section{B}

$(+)$
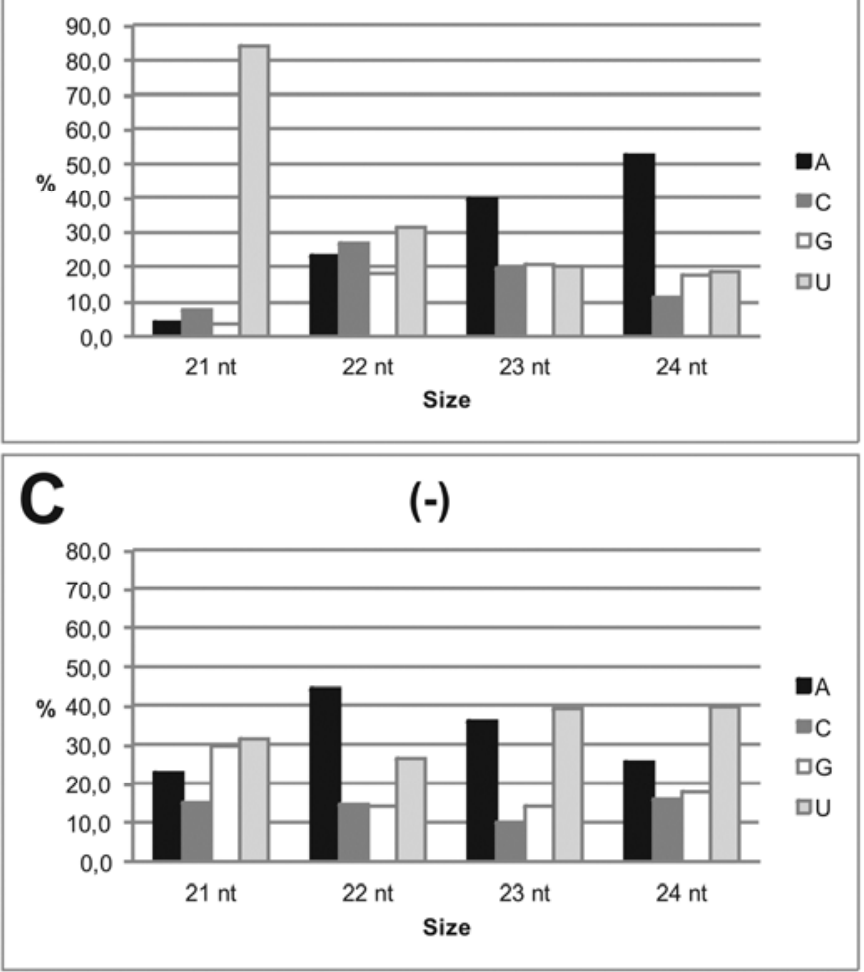

Fig. 5. Characterization of the $5^{\prime}$ terminal nucleotide of virus-derived small RNAs (vsRNAs) from Citrus vein enation virus (CVEV). Relative abundance of the different $5^{\prime}$ nucleotides in $\mathbf{A}$, total, $\mathbf{B},(+)$, and $\mathbf{C},(-)$ 21- to 24-nt vsRNAs in a CVEV-infected plant. sponsible for inciting vein enation symptoms, the perfect match between CVEV detection by RT-PCR or dot-blot hybridization and positive diagnostic of vein enation by biological indexing on Mexican lime strongly suggests that CVEV must be the causal agent of vein enation disease.

Analysis of reads obtained by deep sequencing the VE library showed that the proportion of vsRNAs on the total sRNA reads was about $14.21 \%$, a ratio significantly lower than that found by deep sequencing Citrus tristeza virus (CTV) vsRNAs in CTVinfected sweet orange or Mexican lime plants (about 53\%), but higher than that obtained from CTV-infected sour orange plants (3.5\%) (54) or from cotton plants infected with Cotton leafroll dwarf virus (CLRDV), another member of the family Luteoviridae (6\%) (57). These variations in the vsRNA ratio probably result from intrinsic differences in viral accumulation or in the efficiency of RNA silencing in each virus-host system.

The 21-nt size vsRNAs were prevalent in CVEV-infected plants, with those of (+) polarity being in excess with respect to those of (-) polarity. Assuming that specificity of DICER ribonucleases was conserved in Citrus and Arabidopsis, predominance of the 21-nt vsRNAs would indicate that DCL4 ribonuclease plays the main role in the biogenesis of CVEV vsRNAs $(15,53)$. Predominant accumulation of 21-nt vsRNAs has been reported for several plant viruses infecting different host plants $(9,12,13,67)$, albeit slightly higher 22 - than 21 -nt vsRNAs accumulation was observed in CTV-infected citrus and CLRDVinfected cotton plants $(54,57)$ and a predominant 22-nt vsRNAs population was also detected in plants infected with other viruses and viroids $(13,38)$. Preferential accumulation of (+) vsRNAs, also observed with other plant viruses, supports a model whereby highly structured single-stranded regions of the gRNA would serve as substrate for DCL-mediated cleavage $(14,44)$.

In Arabidopsis, the 5'-terminal nucleotide of sRNAs determines their preference for different Argonaute (AGO) RNases in the RISC to target new RNA molecules. AGO1 has preference for a $5^{\prime}$ $\mathrm{U}, \mathrm{AGO} 2$ and AGO4 for a $5^{\prime} \mathrm{A}$, and AGO5 for a $5^{\prime} \mathrm{C}(41,59)$. Analysis of the CVEV vsRNAs showed a clear predominance of
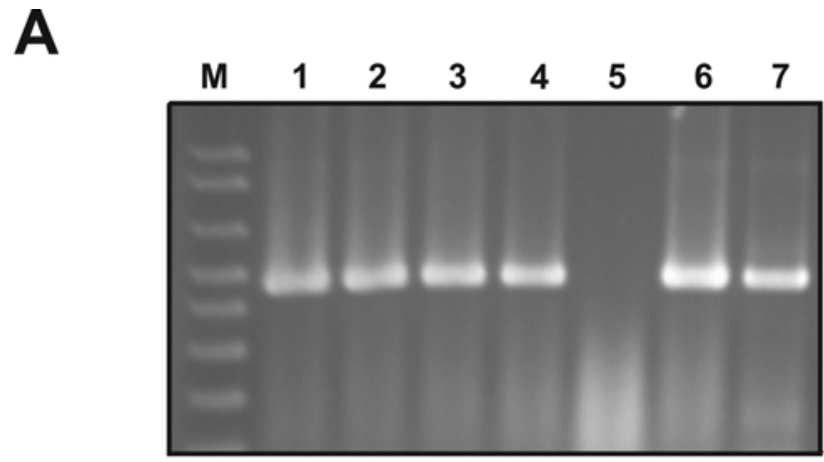

B

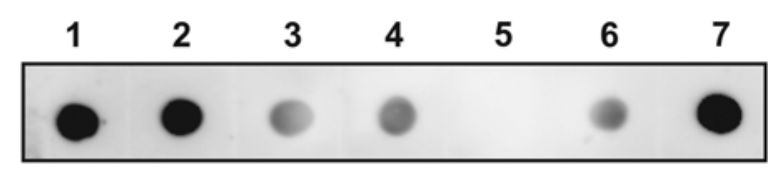

Fig. 6. Detection of Citrus vein enation virus by $\mathbf{A}$, reverse transcriptionpolymerase chain reaction (RT-PCR) and $\mathbf{B}$, dot-blot hybridization. Young bark total RNA extracts from vein enation-infected Valencia late sweet orange (lane 1), Nova mandarin (lane 2), Ortanique tangor (lane 3), and Owari satsuma (lane 4) field trees grafted on Carrizo citrange, from noninoculated (lane 5) or vein enation-inoculated (lane 6) Mexican lime seedlings, or from a rough lemon seedling showing vein enation-woody gall symptoms (lane 7) were used for analysis. Primers VE5f/VE15r and a POL cDNA probe were used for RT-PCR and dot-blot hybridization, respectively. M, 1-kb Plus DNA Ladder (Invitrogen). 
$\mathrm{U}$ and $\mathrm{A}$ at their $5^{\prime}$ terminus, as reported for other viral infections (12). This bias toward $5^{\prime} \mathrm{U}$ and A was more evident considering that nucleotide composition of CVEV gRNA is A (24.52\%), U (25.05\%), G (26.39\%), and C (24.3\%), and it suggests that CVEV vsRNAs may be preferentially loaded into the RISC by AGO1 and AGO2 or AGO4. Analysis of Turnip mosaic virus vsRNAs also showed an overrepresentation of $U$ at their $5^{\prime}$ end (19), suggesting that the $5^{\prime}$ terminal $U$ stabilizes the vsRNAs in vivo through association with AGO1, the main Argonaute protein involved in RNA silencing antiviral defense $(45,72)$.

CVEV vsRNAs were not evenly distributed along the gRNA, with a major hotspot being observed between positions 530 and 552 in the gRNA, and several minor hotspots in ORFs 3 and 5, an asymmetrical distribution that was confirmed by the intense hybridization signal observed in northern blot analysis with a riboprobe complementary to the hotspot region. Most of the vsRNAs of the main hotspot were of $(+)$ polarity, suggesting a major contribution of gRNA secondary structure to vsRNAs formation; however, MFOLD analysis did not predict significant base pairing in this gRNA region. Direct association between vsRNA hotspots and highly structured regions in the gRNAs has never been proved $(12,26,49)$ and preferential accumulation of vsRNAs in certain regions might be due to other viral factors. The relative abundance of vsRNAs from the $3^{\prime}$ proximal region of the CVEV gRNA could be due to production of a sgRNA to express ORFs 3 and 5 in the family Luteoviridae, thus providing an additional dsRNA template during viral replication. Higher accumulation of vsRNAs from the genome region encompassing genes expressed via sgRNAs has been previously reported $(13,47,54,57)$.

The pea enation mosaic disease is induced just when plants are co-infected by PEMV-1, presently the only member of the genus Enamovirus, and PEMV-2, a member of the genus Umbravirus $(6,8)$. These two viruses act in obligate symbiosis, since PEMV-1 depends on proteins encoded by PEMV-2 for long-distance and cell-to-cell movement $(5,7)$ and umbraviruses depend on the assistance of luteoviruses for encapsidation and aphid transmission (51). None of the contigs assembled from the VE sRNA library had similarity with available umbravirus sequences. However, CVEV was always detected by RT-PCR or hybridization in the new flushes of citrus plants graft inoculated with vein enationinducing isolates, suggesting that CVEV is able to systemically infect plants without the presence of an umbravirus. The gRNA of luteo- and poleroviruses contains an ORF 4 encoding a cell-tocell movement protein, but this ORF is absent in PEMV-1 and CVEV gRNAs. On the other hand, it has been reported that the protein encoded by the ORF 5 of several luteoviruses could be involved in systemic spread of these viruses (reviewed in Stevens et al. [58]). Thus, the protein encoded by the CVEV ORF 5 could be responsible for its long-distance movement, or alternatively, some other viral protein could be involved in CVEV systemic movement.

Although Spain is the only country within the European Union in which citrus vein enation disease has been reported, the pathogen might be also present in other countries albeit unnoticed because the woody gall-sensitive species Rangpur lime, rough lemon, and $C$. volkameriana are infrequent rootstocks in the area, and the vein enation symptom in leaves is difficult to observe. Presently, vein enation is a quarantine disease within the European Union and the safe movement of citrus plants and budwood requires certification (Directive 2000/29/EC). So far the only way to diagnose vein enation is biological indexing on sensitive indicator plants, a slow and expensive procedure that requires appropriate greenhouse facilities and well trained personnel. Sequencing of the CVEV gRNA in this work enabled development of quick and cheap methods for specific detection of the virus by dot-blot hybridization or RT-PCR. These methods have already been adopted by the Spanish sanitation, quarantine and certifi- cation programs. Moreover, they will be useful in other programs and also to (i) survey the actual CVEV incidence in different citrus areas, (ii) develop epidemiological studies in the field, and (iii) evaluate potential resistance to the virus of different citrus species and cultivars that could be used in future genetic improvement programs.

\section{ACKNOWLEDGMENTS}

The nucleotide sequence obtained in this work has been deposited in the European Nucleotide Archive under accession number HF679486. M. C. Vives was recipient of a contract from IVIA. This work was supported by grants Proy_IVIA09/02 from IVIA, Project Prometeoll/2013/008 from Generalitat Valenciana, and AGL2009-08226 and AGL2012-32429, cofinanced by FEDER and by the Ministerio de Ciencia e Innovación (MICINN). We thank M. Boil for her excellent lab assistance.

\section{LITERATURE CITED}

1. Altschul, S. F., Madden, T. L., Schaffer, A. A., Zhang, J., Zhang, Z., Miller, W., and Lipman, D. J. 1997. Gapped BLAST and PSI-BLAST: A new generation of protein database search programs. Nucleic Acids Res. 25:3389-3402.

2. Arregui, J. M., Ballester, J. F., Pina, J. A., and Navarro, L. 1982. Influencia del sustrato y de la fertilización en el crecimiento de plantas de lima Mejicana (Citrus aurantifolia (Chritm.) Swing) cultivadas en invernadero. An. Inst. Nac. Invest. Agrar. Ser. Agric. 19:61-82.

3. Clark, C. C., and da Graça, J. V. 2000. Detection of Citrus vein enation virus using Cereal yellow dwarf virus ELISA kits. Pages 357-359 in: Proc. 14th Conf. Intern. Organization Citrus Virol. J. V. da Graça, R. F. Lee, and R. K. Yokomi, eds. IOCV, Riverside, CA.

4. da Graça, J. V., and Maharaj, S. B. 1991. Citrus vein enation virus, a probable luteovirus. Pages 391-394 in: Proc. 11th Conf. Intern. Organization Citrus Virol. R. H. Brlansky, R. F. Lee, and L. W. Timmer, eds. IOCV, Riverside, CA.

5. Demler, S. A., Borkhsenious, O. N., Rucker, D. G., and de Zoeten, G. A. 1994. Assessment of the autonomy of replicative and structural functions encoded by the luteo-phase of Pea enation mosaic virus. J. Gen. Virol. 75:997-1007.

6. Demler, S. A., and de Zoeten, G. A. 1991. The nucleotide sequence and luteovirus-like nature of RNA 1 of an aphid non-transmissible strain of Pea enation mosaic virus. J. Gen. Virol. 72:1819-1834.

7. Demler, S. A., Rucker, D. G., and de Zoeten, G. A. 1993. The chimeric nature of the genome of Pea enation mosaic virus: The independent replication of RNA 2. J. Gen. Virol. 74: 1-14.

8. de Zoeten, G. A., and Skaf, J. S. 2001. Pea enation mosaic and the vagaries of a plant virus. Adv. Virus Res. 57:323-350.

9. Ding, S. W., and Voinnet O. 2007. Antiviral immunity directed by small RNAs. Cell 130:413-426.

10. DiSerio, F., Martínez de Alba, A. E., Navarro, B., Gisel, A., and Flores, R. 2010. RNA-dependent RNA polymerase 6 delays accumulation and precludes meristem invasion of a nuclear-replicating viroid. J. Virol. 84:2477-2489

11. Domier, L. L. 2012. Family Luteoviridae. Pages 1045-1053 in: Virus Taxonomy: IXth Report of the International Committee on Taxonomy of Viruses. A. M. Q. King, M. J. Adams, E. B. Carstens, and E. J. Lefkowitz, eds. Elsevier Academic Press, London, UK.

12. Donaire, L., Barajas, D., Martínez-García, B., Martínez-Priego, L., Pagán, I., and Llave, C. 2008. Structural and genetic requirements for the biogenesis of Tobacco rattle virus-derived small interfering RNAs. J. Virol. 82:5167-5177.

13. Donaire, L., Wang, Y., González-Ibeas, D., Mayer, K. F., Aranda, M. A., and Llave, C. 2009. Deep-sequencing of plant viral small RNAs reveals effective and widespread targeting of viral genomes. Virology 392:203214.

14. Du, Q. S., Duan, C. G., Zhang, Z. H., Fang, Y. Y., Fang, R. X., Xie, Q., and Guo, H. S. 2007. DCL4 targets Cucumber mosaic virus satellite RNA at novel secondary structures. J. Virol. 81: 9142-9151.

15. Dunoyer, P., Himber, C., and Voinnet, O. 2005. DICER-LIKE 4 is required for RNA interference and produces the 21-nucleotide small interfering RNA component of the plant cell-to-cell silencing signal. Nat. Genet. 37:1356-1360.

16. Fraser, L. R. 1959. Woody gall, a suspected virus disease of rough lemon and other citrus varieties. Proc. Linn. Soc. NSW 84: 332-336.

17. Fusaro, A. F., Correa, R. L., Nakasugi, K., Jackson, C., Kawchuk, L., Vaslin, M. F., and Waterhouse, P. M. 2012. The Enamovirus P0 protein is a silencing suppressor which inhibits local and systemic RNA silencing 
through AGO1 degradation. Virology 426:178-187.

18. Galipienso, L., Vives, M. C., Navarro, L., Moreno, P., and Guerri, J. 2004. Detection of Citrus leaf blotch virus using digoxigenin-labeled cDNA probes and RT-PCR. Eur. J. Plant Pathol. 110:175-181.

19. García-Ruiz, H., Takeda, A., Chapman, E. J., Sullivan, C. M., Fahlgren, N., Brempelis, K. J., and Carrington, J. C. 2010. Arabidopsis RNAdependent RNA polymerases and dicer-like proteins in antiviral defense and small interfering RNA biogenesis during Turnip mosaic virus infection. Plant Cell 22:481-496.

20. Giampetruzzi, A., Roumi, V., Roberto, R., Malossini, U., Yoshikawa, N., La Notte, P., Terlizzi, F., Credi, R., and Saldarelli, P. 2012. A new grapevine virus discovered by deep sequencing of virus- and viroidderived small RNAs in cv. Pinot gris. Virus Res. 163:262-268.

21. Giedroc, D. P., and Cornish, P. V. 2009. Frameshifting RNA pseudoknots: Structure and mechanism. Virus Res. 139: 193-208.

22. Goodstein, D. M., Shu, S., Howson, R., Neupane, R., Hayes, R. D., Fazo, J., Mitros, T., Dirks, W., Hellsten, U., Putnam, N., and Rokhsar, D. S. 2012. Phytozome: A comparative platform for green plant genomics. Nucleic Acids Res. 40(D1):D1178-D1186.

23. Gorbalenya, A. E., and Koonin, E. V. 1993. Comparative analysis of amino-acid sequences of key enzymes of replication and expression of positive-strand RNA viruses: Validity of approach and functional and evolutionary implications. Soviet Sci. Rev., Sect. D: Physicochem. Biol. 11:1-84.

24. Habili, N., and Symons, R. H. 1989. Evolutionary relationship between luteoviruses and other RNA plant viruses based on sequence motifs in their putative RNA polymerases and nucleic acid helicases. Nucleic Acids Res. 17:9543-9555.

25. Hermoso de Mendoza, A., Pina, J. A., Ballester-Olmos, J. F., and Navarro, L. 1993. Persistent transmission of Citrus vein enation virus by Aphis gossypii and Myzus persicae. Pages 361-362 in: Proc. 12th Conf. Intern. Organization Citrus Virol. P. Moreno, J. V. da Graça, and L. W. Timmer, eds. IOCV, Riverside, CA.

26. Ho, T., Wang, H., Pallett, D., and Dalmay, T. 2007. Evidence for targeting common siRNA hotspots and GC preference by plant Dicer-like proteins. FEBS Lett. 581:3267-3272.

27. Kozak, M. 1989. The scanning model for translation: An update. J. Cell Biol. 108:229-241.

28. Kreuze, J. F., Perez, A., Untiveros, M., Quispe, D., Fuentes, S., Barker, I., and Simon, R. 2009. Complete viral genome sequence and discovery of novel viruses by deep sequencing of small RNAs: A generic method for diagnosis, discovery and sequencing of viruses. Virology 388:1-7.

29. Laird, E. F., and Weathers, L. G. 1961. Aphis gossypii, a vector of citrus vein-enation virus. Plant. Dis. Rep. 45:877.

30. Li, H., and Durbin, R. 2010. Fast and accurate long-read alignment with Burrows-Wheeler Transform. Bioinformatics 26: 589-595.

31. Li, X., Ryan, M. D., and Lamb, J. W. 2000. Potato leafroll virus protein P1 contains a serine proteinase domain. J. Gen. Virol. 81:1857-1864.

32. Loconsole, G., Saldarelli, P., Doddapaneni, H., Savino, V., Martelli, G. P., and Saponari, M. 2012. Identification of a single-stranded DNA virus associated with citrus chlorotic dwarf disease, a new member in the family Geminiviridae. Virology 432:162-172.

33. Maharaj, S. B., and da Graça, J. V. 1988. Observation of isometric viruslike particles associated with citrus vein enation-infected citrus and the viruliferous aphid vector Toxoptera citricidus. Phytophylactica 20:357360.

34. Maharaj, S. B., and da Graça, J. V. 1989. Transmission of citrus vein enation virus by Toxoptera citricidus. Phytophylactica 21:81-82.

35. Mäkinen, K., Mäkeläinen, K., Arshava, N., Tamm, T., Merits, A., Truve, E., Zavriev, S., and Saarma, M. 2000. Characterization of VPg and the polyprotein processing of Cocksfoot mottle virus (genus Sobemovirus). J. Gen. Virol. 81:2783-2789.

36. Mäkinen, K., Tamm, T., Næss, V., Truve, E., Puurand, U., Munthe, T., and Saarma, M. 1995. Characterization of Cocksfoot mottle sobemovirus genomic RNA and sequence comparison with related viruses. J. Gen. Virol. 76:2817-2825.

37. Martin, R. R., Keese, P. K., Young, M. J., Waterhouse, P. M., and Gerlach, W. L. 1990. Evolution and molecular biology of luteoviruses. Annu. Rev. Phytopathol. 28:341-363.

38. Martínez, G., Donaire, L., Llave, C., Pallás, V., and Gómez, G. 2010. High-throughput sequencing of Hop stunt viroid-derived small RNAs from cucumber leaves and phloem. Mol. Plant Pathol. 11:347-359.

39. Mayo, M. A., and Ziegler-Graff, V. 1996. Molecular biology of luteoviruses. Adv. Virus Res. 56:413-460.

40. McClean, A. P. D. 1954. Citrus vein-enation virus. South Afr. J. Sci. 50:147-151.

41. Mi, S., Cai, T., Hu, Y., Chen, Y., Hodges, E., Ni, F., Wu, L., Li, S., Zhou, H., Long, C., Chen, S., Hannon, G. J., and Qi, Y. 2008. Sorting of small RNAs into Arabidopsis argonaute complexes is directed by the $5^{\prime}$ terminal nucleotide. Cell 133:116-127.
42. Miller, W. A., Brown, C. M., and Wang, S. 1997. New punctuation for the genetic code: Luteovirus gene expression. Semin. Virol. 8:3-13.

43. Miller, W. A., and Giedroc, D. P. 2010. Ribosomal frameshifting in decoding plant viral RNAs. Pages 193-220 in: Recoding: Expansion of Decoding Rules Enriches Gene Expression. J. F. Atkins and R. F. Gesteland, eds. Springer, NY.

44. Molnár, A., Csorba, T., Lakatos, L., Várallyay, É., Lacomme, C., and Burgyán, J. 2005. Plant virus derived siRNAs predominantly originate from highly structured single-stranded viral RNAs. J. Virol. 79:78127818.

45. Morel, J. B., Godon, C., Mourrain, P., Béclin, C., Boutet, S., Feuerbach, F., Proux, F., and Vaucheret, H. 2002. Fertile hypomorphic ARGONAUTE (ago1) mutants impaired in post-transcriptional gene silencing and virus resistance. Plant Cell 14:629-639.

46. Moreno, P. 2000. Protuberancias nerviales-Agallas de la madera (Vein enation-Woody gall). Pages 74-75 in: Enfermedades de los cítricos. Monografía de la Sociedad Española de Fitopatología no. 2. N. DuranVila and P. Moreno, eds. Ediciones Mundi-Prensa, Madrid, Spain.

47. Pantaleo, V., Saldarelli, P., Miozzi, L., Giampetruzzi, A., Gisel, A., Moxon, S., Dalmay, T., Bisztray, G., and Burgyan, J. 2010. Deep sequencing analysis of viral short RNAs from an infected Pinot noir grapevine. Virology 408:49-56.

48. Pfeffer, S., Dunoyer, P., Heim, F., Richards, K. E., Jonard, G., and Ziegler-Graff, V. 2002. P0 of Beet western yellows virus is a suppressor of posttranscriptional gene silencing. J. Virol. 76:6815-6824.

49. Qi, X., Bao, F. S., and Xie, Z. 2009. Small RNA deep sequencing reveals role for Arabidopsis thaliana RNA-dependent RNA polymerases in viral siRNA biogenesis. PLoS One 4(3):e4971.

50. Radford, A. D., Chapman, D., Dixon, L., Chantrey, J., Darby, A. C., and Hall, N. 2012. Application of next-generation sequencing technologies in virology. J. Gen. Virol. 93:1853-1868.

51. Robinson, D. J., and Murant, A. F. 1999. Umbraviruses. Pages 1855-1859 in: Encyclopedia of Virology. A. Granoff and R. G. Webster, eds. Academic Press, NY.

52. Roistacher, C. N. 1991. Graft-Transmissible Diseases of Citrus. Handbook for Detection and Diagnosis. FAO, Rome, Italy.

53. Ruiz-Ferrer, V., and Voinnet, O. 2009. Roles of plant small RNAs in biotic stress responses. Annu. Rev. Plant Biol. 60:485-510.

54. Ruiz-Ruiz, S., Navarro, B., Gisel, A., Peña, L., Navarro, L., Moreno, P., Di Serio, F., and Flores, R. 2011. Citrus tristeza virus infection induces the accumulation of viral small RNAs (21-24-nt) mapping preferentially at the 3 -terminal region of the genomic RNA and affects the host small RNA profile. Plant Mol. Biol. 75:607-619.

55. Sambrook, J., Fritsch, E. F., and Maniatis, T. 1989. Molecular Cloning: A Laboratory Manual. Cold Spring Harbor Laboratory, Cold Spring Harbor, NY.

56. Schulz, M. H., Zerbino, D. R., Vingron, M., and Birney, E. 2012. Oases: Robust de novo RNA-seq assembly across the dynamic range of expression levels. Bioinformatics 28:1086-1092.

57. Silva, T. F., Romanel, E. A., Andrade, R. R., Farinelli, L., Østerås, M., Deluen, C., Corrêa, R. L., Schrago, C. E., and Vaslin, M. F. 2011. Profile of small interfering RNAs from cotton plants infected with the polerovirus Cotton leafroll dwarf virus. BMC Mol. Biol. 24:12-40.

58. Stevens, M., Freeman, B., Liu, H. Y., Herrbach, E., and Lemaire, O. 2005. Beet poleroviruses: Close friends or distant relatives? Mol. Plant Pathol. 6:1-9.

59. Takeda, A., Iwasaki, S., Watanabe, T., Utsumi, M., and Watanabe, Y. 2008. The mechanism selecting the guide strand from small RNA duplexes is different among argonaute proteins. Plant Cell Physiol. 49:493500 .

60. Tamura, K., Peterson, D., Peterson, N., Stecher, G., Nei, M., and Kumar, S. 2011. MEGA5: Molecular evolutionary genetics analysis using maximum likelihood, evolutionary distance, and maximum parsimony methods. Mol. Biol. Evol. 28:2731-2739.

61. Thompson, J. D., Higgins, D. G., and Gibson, T. J. 1994. Improving the sensitivity of progressive multiple sequence alignment through sequence weighing positions-specific gap penalties and weigh matrix choice. Nucleic Acids Res. 22:4673-4680.

62. Vives, M. C., Martín, S., Ambrós, S., Renovell, Á., Navarro, L., Pina, J A., Moreno, P., and Guerri, J. 2008. Development of a full-genome cDNA clone of Citrus leaf blotch virus and infection of citrus plants. Mol. Plant Pathol. 9:787-797.

63. Wallace, J. M., and Drake, R. J. 1953. A virus-induced vein enation in citrus. Citrus Leaves 33:22-24.

64. Wallace, J. M., and Drake, R. J. 1959. Citrus vein enation. Pages 163-165 in: Citrus Virus Diseases. J. M. Wallace, ed. Univ. Calif. Div. Agric. Sci., Berkley, CA.

65. Wallace, J. M., and Drake, R. J. 1960. Woody galls on citrus associated with vein-enation virus infection. Plant Dis. Rep. 44:580-584.

66. Wallace, J. M., and Drake R. J. 1961. Induction of woody galls by wound- 
ing of citrus infected with vein enation virus. Plant Dis. Rep. 45:682-686.

67. Wang, X. B., Jovel, J., Udomporn, P., Wang, Y., Wu, Q., Li, W. X., Gasciolli, V., Vaucheret, H., and Ding, S. W. 2011. The 21-nucleotide, but not 22-nucleotide, viral secondary small interfering RNAs direct potent antiviral defense by two cooperative Argonautes in Arabidopsis thaliana. Plant Cell 23:625-638.

68. Wu, Q., Luo, Y., Lu, R., Lau, N., Lai, E. C., Li, W. X., and Ding, S. W. 2010. Virus discovery by deep sequencing and assembly of virus-derived small silencing RNAs. Proc. Natl. Acad. Sci. USA 107:1606-1611.

69. Yaegashi, H., Takahashi, T., Isogai, M., Kobori, T., Ohki, S., and Yoshikawa, N. 2007. Apple chlorotic leaf spot virus $50 \mathrm{kDa}$ movement protein acts as a suppressor of systemic silencing without interfering with local silencing in Nicotiana benthamiana. J. Gen. Virol. 88:316-324.

70. Zerbino, D. R., and Birney, E. 2008. Velvet: Algorithms for de novo short read assembly using de Bruijn graphs. Genome Res. 18:821-829.

71. Zhang, Y., Singh, K., Kaur, R., and Qiu, W. 2011. Association of a novel DNA virus with the grapevine vein-clearing and vine decline syndrome. Phytopathology 101:1081-1090.

72. Zhang, X., Yuan, Y. R., Pei, Y., Lin, S. S., Tuschl, T., Patel, D. J., and Chua, N. H. 2006. Cucumber mosaic virus-encoded 2b suppressor inhibits Arabidopsis Argonaute1 cleavage activity to counter plant defense. Genes Dev. 20:3255-3268.

73. Zuker, M. 2003. Mfold web server for nucleic acid folding and hybridization prediction. Nucleic Acids Res. 31:3406-3415. 